\title{
Characterization of dissolved organic matter from a restored urban marsh and its role in the mobilization of trace metals
}

\author{
Hagar ElBishlawi, Peter R. Jaffe* \\ Department of Civil and Environmental Engineering, Princeton University, Princeton, NJ 08544, USA
}

\section{A R T I C L E I N F O}

\section{Article history:}

Received 7 August 2014

Received in revised form 17 December 2014

Accepted 24 December 2014

Handling Editor: Keith Maruya

\section{Keywords:}

Constructed marsh

DOM

Restored marsh

Trace metals

\begin{abstract}
A B S T R A C T
Dissolved organic matter (DOM), although highly variable and not very well characterized, plays a role in many important environmental reaction and transport processes, including trace metal mobilization. This study characterizes heterogeneous DOM from the pore-water of a restored urban tidal marsh, using chemical, optical, and electrochemical methods for dissolved organic carbon/nitrogen ratios (C:N: 1.86.4), spectroscopic characteristics (decreased aromaticity in amended sediments), element ratios (maximum sediment-associated trace metal concentrations measured $<30 \mathrm{~cm}$ ), and metal complexation properties $\left(\log K_{c}\right.$ : Cd: $10.7 \pm 0.7>\mathrm{Pb}: 9.5 \pm 0.1>\mathrm{Cr}$ : $7.3 \pm 0.1>\mathrm{Cu}: 5.07 \pm 0.53$ ), all as a function of sediment depth.

Specific DOM properties from the restored marsh were then compared to pore-water samples from a natural marsh and a simulated wetland microcosm which resulted in similar values, while the reference humic acid significantly differed in properties from field DOM. The results revealed that reference humic acids do not accurately represent the complexity of natural heterogeneous DOM, whereas a simulated wetland microcosm may provide a reasonable representation of natural DOM.

Clear differences between amended and original soil (transition below $30 \mathrm{~cm}$ ) were observed in DOM and trace metal properties including: lower DOM content, higher $\log K_{c}$ values, less DOM complexity, development of a iron-sulfide redox buffering pool, and greater affinity for metals in the solid phase occurring in the amended sediments.
\end{abstract}

(c) 2015 Elsevier Ltd. All rights reserved.

\section{Introduction}

Dissolved organic matter (DOM) in wetland sediments is the result of biodegradation of more complex organic material as well as root exudates, producing diverse mixtures of functional groups which can interact strongly with trace metals. Natural organic matter can create avenues for both metal immobilization and transport. Trace metals such as $\mathrm{Cd}, \mathrm{Cr}, \mathrm{Cu}$, and $\mathrm{Pb}$ can also be removed from solution through processes such as precipitation and sorption (Weber et al., 1991; Al-Farawati and van den Berg, 1999; Du Laing et al., 2009; Mostofa et al., 2013). Organic matter can provide physical sites for metal adsorption and electron donors for sulfate reduction, resulting in sulfide-metal precipitation (Sundelin and Erikkson, 2001). DOM can also enhance metal mobilization via complexation mechanisms expressed in the simplest case by Eq. (1) (Chau and Lum-Shue-Chan, 1974; Mantoura et al., 1978; Luther, 2001; Hansell and Carlson, 2002; Weng et al.,

\footnotetext{
* Corresponding author. Tel.: +1 6092584653; fax: +1 6092582760.

E-mail addresses: helbishl@princeton.edu (H. ElBishlawi), jaffe@princeton.edu (P.R. Jaffe).
}

2002; Baken et al., 2011; Mostofa et al., 2013). Some functional groups including carboxylic, phenolic, nitrogen, and sulfur containing groups, have high affinities for metal ions, creating stable complexes of varying complexing strengths $\left(K_{c}\right)$ (Ephraim and Marinsky, 1986; Abate and Masini, 2002; Hansell and Carlson, 2002; Andjelkovic, 2006; Fellman et al., 2008). These interactions will affect the transport and ultimate fate of trace metals (TM). The bioavailability and mobility of these contaminants are governed by the competition between precipitation/sorption and complexation.

$\mathrm{Me}^{2+}+$ Org $\leftrightarrow$ MeOrg

Models simulating metal DOM binding are often based on complexation constants derived from extracted humic substances such as humic and fulvic acids or other organic ligands, which may not accurately represent the DOM found in field conditions (Susetyo et al., 1991). The concentration, composition, and chemistry of DOM are highly variable and dependent on the sources of organic matter and other environmental features including temperature, ionic strength, $\mathrm{pH}$, surface chemistry, and system microbiology 
(Leenheer and Croue, 2003). Therefore, rather than utilizing previously characterized, commercially available humic substances, this study will characterize chemically distinct natural DOM.

Measurement of bulk properties of dissolved organic matter such as light absorptivity can yield important information describing its chemical reactivity and mobility (Chin et al., 1994). In addition to spectroscopic methods, elemental ratios such as $\mathrm{C}: \mathrm{N}$ are commonly used to indicate the biodegradability of DOM (Fellman et al., 2008).

To determine if differences in DOM properties in sediments of a newly constructed marsh correlate with changes in metal binding capacities, the complexation properties of the DOM are evaluated for pore-water samples. Because it is generally not well understood how heterogeneous dissolved organic matter (DOM) varies as a function of depth in constructed tidal estuarine wetlands, samples were investigated as a function of depth (Mann and Wetzel, 1995; Barber et al., 2001; Laudon et al., 2011). Natural DOM properties are likely to change within the soil profile due to changes in the redox environment, DOM age, and nature of soil (amended or original sediment). A novel experimental design was implemented with high-resolution in-situ pore-water samples collected as a function of depth to capture these trends.

The objective of this research was to contrast the metal-DOM interactions in a newly constructed versus a natural marsh. To achieve these goals we (a) characterized how dissolved organic matter changes with depth between a restored and natural marsh, (b) determined spectroscopic properties of pore-water samples, (c) quantified how DOM properties drive metal complexation, (d) compared specific DOM characteristics with simulated wetland microcosm pore-waters, reference humic acid, and literature values, and (e) modeled how changes in concentration of DOM, iron, salinity, and sulfide affect metal organic complexation over a range of values measured in the field.

\section{Methodology}

\subsection{Field description}

To measure metal-DOM interactions, samplers were deployed in two tidally influenced urban wetlands, one of which was a restored marsh and the other a natural marsh (Fig. S1a). Under the Wetlands Act of 1970 (N.J.S.A. 13:9A-1 et seq.), coastal wetlands are under regulation and must be permitted to be excavated, dredged, filled, or placement of a structure, and authorize construction/remediation of a wetland in response to development. One such restored wetland named the Secaucus High School March was completed in 2007 within the New Jersey Meadowlands along the Hackensack River (40.804 Lat., -74.047 Long.). Briefly, a surface layer of clean engineered sediments consisting of a core of freshwater pond dredge and $15 \mathrm{~cm}$ cap of sand replaced approximately $0.5 \mathrm{~m}$ of original surface sediment. The material tapers toward the periphery of the marsh areas producing a sediment layer of fresh surface material less than $25 \mathrm{~cm}$ in the high marsh. The natural marsh is located four miles downstream of the constructed marsh (40.771 Lat., -74.086 Long.). A detailed description of these field sites is provided in ElBishlawi et al. (2013). These marshes are brackish with Phragmites australis, Spartina patens, and Spartina alterniflora as the dominant plant species.

\subsection{Pore-water collection}

Dialysis samplers were deployed to collect pore-water without disturbing surrounding sediments. The samplers used are described in detail (ElBishlawi et al., 2013; MacDonald et al., 2013). Briefly, twenty chambers spaced at $4 \mathrm{~cm}$ intervals up to a depth of $60 \mathrm{~cm}$ were perforated into a plastic block and were covered by a $0.2 \mu \mathrm{m}$ membrane (GE) and secured with a rubber gasket and a plastic frame. Two capped polypropene tubes connected to each chamber allow for the in-situ sample withdrawal and input of inert fill gas (argon) during sampling, and deoxygenated and deionized water (DDIW) after sampling. The volume of each chamber was approximately $60 \mathrm{~mL}$ with a sediment contact area of $0.127 \mathrm{~cm}^{2} \mathrm{~mL}^{-1}$. DDIW-filled chambers were allowed to equilibrate with the sediment pore-waters for at least 4 weeks before sampling.

\subsection{Sediment collection}

In September 2010, a detailed sediment profile was obtained using a Russian peat-corer taken in $50 \mathrm{~cm}$ sections with each grab. Samples were immediately wrapped with cellophane and stored under $\mathrm{N}_{2}$ gas at $4{ }^{\circ} \mathrm{C}$. The vertical distribution of sediment properties was examined via sectioning into $4 \mathrm{~cm}$ depth segments in an anaerobic glove box $\left(3 \% \mathrm{H}_{2}: 97 \% \mathrm{~N}_{2}\right)$. The $4 \mathrm{~cm}$ segments were placed in plastic Ziploc ${ }^{\circledR}$ bags filled with nitrogen gas and refrigerated until analyzed. Additionally, grab samples were taken in July 2009. Solid-phase metals were extracted using $2 \mathrm{~N} \mathrm{HCl}$ and full strength $\mathrm{HNO}_{3}$ for $24 \mathrm{~h}$ with concentrations determined by atomic absorption spectroscopy (Chau and Lum-Shue-Chan, 1974; ElBishlawi et al., 2013).

\subsection{Simulated wetland microcosm and laboratory sample collection}

To compare characteristics of DOM from field samples with simulated wetland samples, pore-water was withdrawn from greenhouse microcosm, described in detail by MacDonald (2010). Briefly, lurid sedge (Carex lurida) was planted in saturated microcosms with dimensions of $25.4 \mathrm{~cm}$ in diameter and $36.8 \mathrm{~cm}$ in height with nine sampling port-holes distributed equally along the depth (see Fig. S1b). The microcosms were established February 2009 and sampled July 2009. Tap water, amended with $1 \mathrm{mM}$ sodium acetate, was used to stimulate microbes and lower the redox potential. The flow rate was controlled via peristaltic pumps at $7.5 \mathrm{~mL} \mathrm{~min} \mathrm{~m}^{-1}$ (Isamatec). This microcosm simulates the complexity of plant-soil-water interactions of a wetland system with the simplicity of a column experiment. Pore-water samples were withdrawn from ports, filtered with a $0.2 \mu \mathrm{m}$ filter, and then processed for analysis of DOM absorption characteristics and the complexation constant for $\mathrm{Cd}(\mathrm{II})$ was then determined. Additionally, complexation (DOM-Cu(II) and $\mathrm{Pb}(\mathrm{II})$ ) and spectroscopic properties of commercially obtained reference humic acid (sodium salt, Aldrich, lot number 04607BI, CAS: 68131-04-4) at concentrations of $25 \mathrm{mg} \mathrm{L}^{-1}$ and $50 \mathrm{mg} \mathrm{L}^{-1}$ with deionized water were also measured to compare with the field and mesocosm values.

\subsection{Analytical measurements}

Spectroscopy of DOM was conducted at different wavelengths (254 nm, $280 \mathrm{~nm}, 287 \mathrm{~nm}, 400 \mathrm{~nm}$, and $600 \mathrm{~nm}$ ) to characterize UV and visible light absorbing components (Thermo Fisher Scientific Spectronic Genesys 2 UV-Vis Spectrophotometer). Dissolved organic carbon and nitrogen were analyzed with a Total Carbon/ Total Nitrogen Analyzer (Shimadzu). Ion chromatography measurements were performed on a Dionex DX-500 system with a 2-mm ASRS-300 suppressor, a CD-25 conductivity detector to measure inorganic anions. Additionally pore-water samples were collected in April 2014 for analysis of C:N (DOM). Dissolved organic nitrogen was calculated as the difference between measured values of total dissolved nitrogen and inorganic nitrogen $\left(\mathrm{NO}_{3}^{-}\right.$and $\mathrm{NO}_{2}^{-}$and $\mathrm{NH}_{4}^{+}$). An Atomic Absorption Spectrophotometer (Varian SpectrAA-220) was utilized to measure dissolved trace metals 
and select elements including total dissolved $\mathrm{Cd}, \mathrm{Cu}, \mathrm{Cr}, \mathrm{Fe}$, and $\mathrm{Pb}$ (ElBishlawi et al., 2013).

\subsection{DOM-metal complexation measurements}

Metal complexation measurements were performed via voltammetry (Rozan et al., 1999; Kovaleva, 2004; Andjelkovic, 2006). An AIS Model DLK-100A Electrochemical Analyzer Rev 3.3 was used to the determine complexation capacity of metals with DOM. The electrochemical analyzer was configured with a threeelectrode system consisting of a gold amalgam indicator electrode, $\mathrm{Ag} / \mathrm{AgCl}$ reference electrode, and a platinum auxiliary electrode. The reaction cell was filled with a buffer system of $1 \mathrm{~mL} 0.1 \mathrm{M}$ HEPES and $1 \mathrm{~mL} 0.1 \mathrm{M} \mathrm{KNO}_{3}$ as the electrolyte. The cell was degassed and purged with argon gas for two minutes. Pore-water and dissolved metals were then injected into the system. Hg deposition was initiated at a potential of $-1.5 \mathrm{~V}$ using $2 \times 10^{-5} \mathrm{M}$ $\mathrm{Hg}\left(\mathrm{NO}_{3}\right)_{2}$ for $60 \mathrm{~s}$. A scan was then performed from $-1.0 \mathrm{~V}$ to $0.2 \mathrm{~V}$ at $20 \mathrm{mV} \mathrm{s}^{-1}$ with pulse height of $50 \mathrm{mV}$, using the square wave technique. Standard curves were utilized to determine the relationship between the current increase and concentration values at characteristic potential values. Free metal concentrations of $\mathrm{Cd}(\mathrm{II}), \mathrm{Cr}(\mathrm{III}), \mathrm{Cu}(\mathrm{II})$, and $\mathrm{Pb}(\mathrm{II})$ were measured at peak potentials of $-0.55 \mathrm{~V},-0.05 \mathrm{~V},-0.70 \mathrm{~V}$, and $-0.65 \mathrm{~V}$, respectively. Both titrations of metals (using the Ruzic method) and titrations of DOM (using the Scatchard method) produced similar $\log K_{c}$ values (Ruzic, 1996).

\subsection{Thermodynamic modeling}

Chemical models can provide a description of metal speciation to determine how dissolved DOM species can compete for trace metals and describe what species may be formed (Goldberg, 1995; Goldberg et al., 2007). A chemical speciation model, MINTEQA2 v.4.03, was used to predict the system behavior (USEPA, 2006). The effect of the concentration of DOM, sulfide, iron, and ionic strength/salinity on metal complexation was modeled using MINTEQA2. Experiments tested the effect of DOM (0.001$\left.200 \mathrm{mg} \mathrm{L}^{-1}\right)$, sulfide $\left(0.001-20 \mathrm{mM} \mathrm{HS}^{-1}\right)$, iron $(0.001-15 \mathrm{mM}$ $\mathrm{Fe}(\mathrm{II}))$ concentrations, and ionic strength/salinity $\left(2 \times 10^{-4} \mathrm{M}\right.$ and $2 \times 10^{-2} \mathrm{M}$ ), to represent the range of field conditions observed (ElBishlawi et al., 2013).

\section{Background on DOC characterization}

\subsection{Spectroscopic analysis}

Light absorptivity can yield important information describing chemical reactivity and is often used to characterize the DOM (Chin et al., 1994; Barber et al., 2001; Guo and Chorover, 2003). The molar absorptivity (Eq. (2)) is a constant that describes the ratio of absorbance at specified wavelengths with concentration of organics in molar units. The specific UV absorbance (SUVA) (Eq. (3)) characterizes absorption in mass units.

$\varepsilon=\frac{\text { absorbance }\left[\mathrm{cm}^{-1}\right]}{\text { DOC concentration }[\mathrm{mol} \mathrm{C} \mathrm{L}}$

SUVA $=\frac{\text { absorbance }\left[\mathrm{m}^{-1}\right]}{\text { DOC concentration }\left[\mathrm{mg} \mathrm{C} \mathrm{L} \mathrm{L}^{-1}\right]}$

Previous studies have used SUVA measured at $254 \mathrm{~nm}$ $\left(\mathrm{SUVA}_{254}\right)$ as a proxy for DOM aromaticity as it is strongly correlated with the percent aromaticity determined by ${ }^{13} \mathrm{C}$ NMR (Weishaar et al., 2003). Absorption properties measured at
$280 \mathrm{~nm}$ and $287 \mathrm{~nm}$ are correlated with both apparent molecular weight and aromaticity of aquatic natural organic matter (Chin et al., 1994; Guo and Chorover, 2003; Leenheer and Croue, 2003).

The color ratio $\left(Q_{4 / 6}\right)$, a measure of the gradient of the spectral curve, characterizes the degree of humification (Eq. (4)). Humic substances with high molecular weight exhibited lower $Q_{4 / 6}$ values, indicating a greater degree of humification (Tan and Giddens, 1972). As an index, high color ratios, 7-8 or higher, correspond to fulvic acids and lower ratios, 3-5, indicate the presence of humic acids (Tan, 2003). Components of DOM, such as fulvic acids are reported to control both absorption of visible and UV light as well as chemical speciation and transport of trace metals through complexation reactions (McKnight et al., 2001). In addition to spectroscopic methods, elemental ratios such as C:N are commonly used to indicate the biodegradability of DOM (Fellman et al., 2008).

$Q_{\frac{4}{6}}=\frac{\text { absorbance at } 400 \mathrm{~nm}}{\text { absorbance at } 600 \mathrm{~nm}}$

\subsection{DOC-metal complexation analysis}

Voltammetric titrations are commonly used to quantify the metal-DOM binding capacity via the conditional stability constant, $K_{c}$ (Baeyens et al., 1998; Al-Farawati and van den Berg, 1999; Luther, 2001). $K_{c}$ describes the interaction between free and complexed metal in association with the organic ligand (Eqs. (5) and (6)).

$\frac{M_{T}-M}{M}=K_{c}\left[S-\left(M_{T}-M\right)\right]$

$\frac{M}{M_{T}-M}=\frac{M}{S}+\frac{1}{K_{c} S}$

where $M_{T}$ is the total metal added, $M$ is the free metal measured, $S$ is the substrate (DOM), and $\left(M_{T}-M\right)$ represents the metal complex. The larger the $K_{c}$, the greater the binding strength is, which results in a more stable complex. The number of bonding sites or chelating ability of ligands and the size of the complex control the stability of the resulting complex (Tipping, 2003). Differences between complexing strength are attributed to metal-ligand interactions.

\section{Results and discussion}

\subsection{Dissolved organic carbon and nitrogen}

The marsh pore-waters collected between 2007 and 2014 were found to be rich in dissolved organic carbon (DOC) with maximum concentrations of $25 \mathrm{mM}$ of C (Fig. S2). Seasonal variation was observed with the highest concentrations observed in the summer and lowest values in the spring. While, the restored and natural marsh displayed similar DOC concentrations, a greater spread of values was observed in the constructed marsh. This indicates while average trends in concentration are similar; the natural marsh produces a more regular output of DOC throughout the year.

Sampling results for April 2014 were typical for the profiles measured and displayed in Fig. 1. While the DOM profiles of the natural marsh remained stable with depth, an increase in both DOC and DON values was observed below $35 \mathrm{~cm}$ in the constructed marsh, (Fig. 1a and b). The stratification in DOM properties in the restored marsh coincided with the depth of transition from the amended sediment to the original sediment.

The ratio of $\mathrm{C}: \mathrm{N}$ (dissolved) was not significantly different between sites above $50 \mathrm{~cm}$, indicating that the DOM was similar in degraded character. Below this depth, the dissolved C: $\mathrm{N}$ ratio indicated that the natural marsh DOM was slightly but significantly more degraded. 

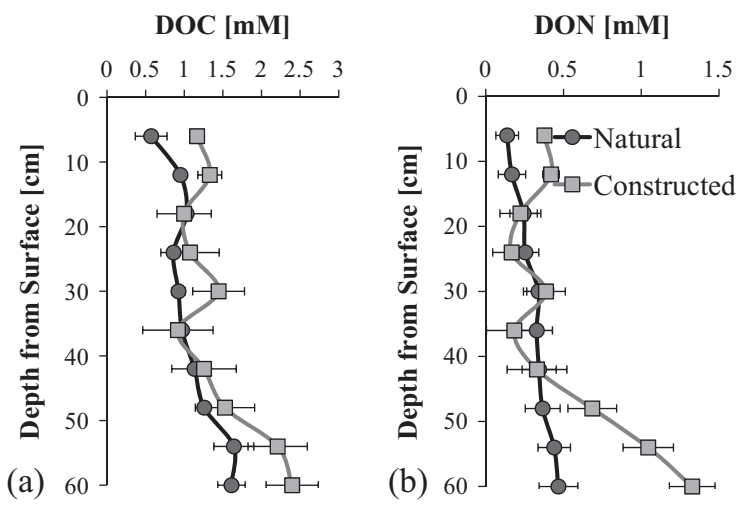

DOC/DON [mM/mM]

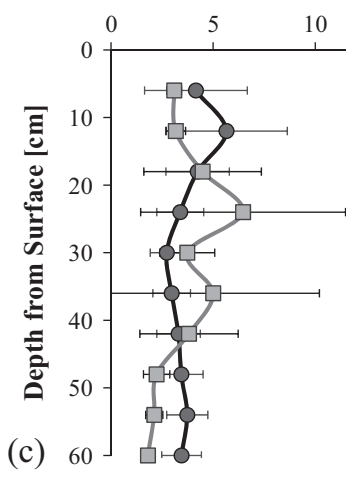

Fig. 1. (a) DOC, (b) DON, and (c) C:N (DOM) ratios for the natural marsh (circle) and constructed marsh (square) sampled in April 2014 with associated standard error.

The DOC concentrations in the simulated wetland microcosm, which had a short operation time of only 3 months, were on the same order of magnitude as natural marsh, but approximately two times lower than field-site concentrations at equivalent depths with an average value of $0.58 \pm 0.16 \mathrm{mM} \mathrm{C}$ (Table S2a). The microcosm represented $38 \mathrm{~cm}$ of sediment and similar to the corresponding field-site profile, no observable trends with depth were measured $(n=33)$.

\subsection{Spectroscopic analyses}

In the natural marsh, no significant trends with depth were observed in DOM absorptivity, with average values in the ultraviolet wavelengths measuring $0.61 \pm 0.58 \mathrm{~L} \mathrm{mg}^{-1} \mathrm{~m}^{-1}, 0.96 \pm 0.86$ $\mathrm{L} \mathrm{mg}^{-1} \mathrm{~m}^{-1}, 1.21 \pm 1.03 \mathrm{~L} \mathrm{mg}^{-1} \mathrm{~m}^{-1}$, for $254 \mathrm{~nm}, 280 \mathrm{~nm}$, and $287 \mathrm{~nm}$ respectively. The values measured at this site fell within previously reported ranges of $\mathrm{SUVA}_{254}$ for aquatic humic acids between $0.6 \mathrm{~L} \mathrm{mg}^{-1} \mathrm{~m}^{-1}$ and $5.1 \mathrm{~L} \mathrm{mg}^{-1} \mathrm{~m}^{-1}$ (Weishaar et al., 2003). The high variability of DOM in these pore-waters is clearly represented by the large errors in the readings. The constructed marsh exhibited much lower variability with depth-averaged values of SUVA, measuring $0.56 \pm 0.28 \mathrm{~L} \mathrm{mg}^{-1} \mathrm{~m}^{-1}, \quad 0.67 \pm 0.31$ $\mathrm{L} \mathrm{mg}^{-1} \mathrm{~m}^{-1}, \quad 0.91 \pm 0.41 \mathrm{~L} \mathrm{mg}^{-1} \mathrm{~m}^{-1}$ for $254 \mathrm{~nm}, 280 \mathrm{~nm}$, and $287 \mathrm{~nm}$, respectively. Clear trends with depth were also observed with absorptivity values, increasing from the surface to about $20 \mathrm{~cm}$ (amended sediment) (Fig. 2a). Below this depth values were not significantly different from SUVA measured in the natural marsh for all wavelengths measured.

The lower absorptivity in the UV wavelengths is indicative of lower aromatic content of DOM in the amended sediments (McKnight et al., 2001). This result implies that the DOM from the amended sediment in the constructed marsh is less complex (less variability) and lower in aromatic content (lower SUVA values). Further differences in DOM character are supported by higher color ratio values in the constructed marsh (Fig. 2b).

The presence of higher color ratios indicated a greater likelihood of the presence of fulvic acids below $35 \mathrm{~cm}$ (Tan and Giddens, 1972; Tan, 2003). Humic acids have lower O:C ratios than fulvic acids, and fulvic acids have extremely high O:N ratios with functional groups such as porphyrin that can facilitate metal binding (Alberts and Filip, 1998). The DOM from the natural marsh remained generally stable, with less variability and lower color ratio values. While the other absorption indices converged in the original sediment of the restored marsh with the natural marsh, $Q_{4 / 6}$ did not. The natural marsh pore-waters steadily exhibited values characteristic of humic acids with depth, while the constructed marsh with pointed to a greater mix of fulvic and humic acids in the sediments. To quantify the relationships between natural DOM properties and metal complexation, correlation studies were performed below (Section 4.4).

The DOM from the simulated wetland microcosm, filled with plant roots, reflected both the absorption values and depth profile of the surficial constructed marsh pore-waters. The $\epsilon_{280}$ from both sources agreed well with $78.6 \pm 5.3 \mathrm{~L} \mathrm{~mol}^{-1} \mathrm{~cm}^{-1}$ from the simulated wetland microcosm and $81.9 \pm 4.6$ from the constructed marsh (Fig. 2a and Table S2a). Note that the microcosms were operating for less than 5 months (as opposed to restored marsh with sediments that had been amended over 3 years prior to sampling). The UV absorption of the reference Aldrich humic acid was over four times larger than values observed in the marsh pore-waters (Table S2b).

\subsection{Complexation analyses}

Dissolved organic ligands have the ability to form soluble complexes with trace metals (Du Laing, 2008). Ranking of measured binding strengths for DOM were $\mathrm{Cd}>\mathrm{Pb}>\mathrm{Cr}$ with average values of $10.7 \pm 0.7,9.5 \pm 0.1$, and $7.3 \pm 0.1$ (Fig. 3 and Table 1 ).

Comparing metal complexation constants of pore-water DOM with pure humic acid (HA) shows that the binding strength for both $\mathrm{Pb}$ and $\mathrm{Cd}$ would be undervalued and $\mathrm{Cr}$ would be overvalued if humic acid was used as the DOM (Table 1). This therefore confirms the need to measure stability constants for natural heterogeneous DOM:metal complexes to obtain a more accurate description of DOM:metal interactions than by simply modeling DOM as humic acid. One such functional group not taken into account by the MINTEQ model is the thiol group. These organic sulfide groups (R-SH) are ubiquitous in wetlands (Zhang and Wang, 2004) and are produced by plants mediating interactions with metals (Joe-Wong et al., 2012). Organic thiol functional groups are important DOM complexing ligands for soft Lewis acids, such as $\mathrm{Cd}$ and $\mathrm{Pb}$. Their presence influences metal speciation and solubility in natural waters (Joe-Wong et al., 2012). Thiols affinity for metals like $\mathrm{Cd}$ and $\mathrm{Pb}$ would result in the higher measured binding capacity values observed in the measured complexation constants for natural waters (see Table 1 ). While the reference humic acid differed in $\log K_{c}$ values (Table 1 ) with the constructed marsh pore-waters, the DOM from samples collected from the simulated wetland microcosm were able to replicate complexation constant values for DOM:Cd. Although the concentration of DOM is lower in the microcosm, the character of DOM, as measured by aromaticity and binding capacity, appear to be well representative of surface pore-waters from the constructed marsh.

\subsection{Correlations between $K_{c}$ and characteristics of DOM}

DOM is comprised of diverse functional groups, which can act as binding sites with different complexing strengths. To 
assess which measured factors were most strongly associated with $\log K_{c}$, correlations coefficients were computed with several DOM properties (Table S1). The $\log K_{c}$ (DOM:Cd) was correlated with the color ratio, implying that greater binding may be associated with DOM of greater fulvic acid content (Tan and Giddens, 1972; Tan, 2003). The $\log K_{c}$ (DOM-Pb) was not strongly associated with any specific UV absorption wavelength. The $\log K_{c}$ (DOM:Cr) was correlated with $\epsilon_{287}$ and inversely correlated with the color ratio and depth. This implies that $\mathrm{Cr}$ had higher binding strength with greater aromatic content and humic acid content. Baken et al. reported that trace metal complexation increased with increasing aromaticity, and with increasing fractions of humic substances (Baken et al., 2011). The constructed marsh DOM contains aromatic groups throughout the depth profile, but above $30 \mathrm{~cm}$ in the amended sediment, these functional groups absorb particularly strong at $280 \mathrm{~nm}$. These changes suggests an increase in polar, oxygencontaining functional groups such as $\mathrm{COOH}$ or $\mathrm{OH}$ that absorbs strongly at $280 \mathrm{~nm}$ and are known to be metal binding sites (Winch and Lean, 2005). Correlations were found between metal-DOM complexation constants and the occurrence of aromatic functional groups ( $\mathrm{Cd}$ and $\mathrm{Cr}$ ). $\mathrm{Pb}$ did not strongly correlate with DOM properties and also did not follow predicted patterns (Section 4.5).

\subsection{Sediment-associated and dissolved metal distributions}

Metals from marsh sediments and pore-waters were measured as a function of depth to determine if a zone of maximum mobilization/immobilization existed (Fig. S4). It was found for all metals measured that the highest concentrations of sediment-associated metal were measured at depths between $20 \mathrm{~cm}$ and $30 \mathrm{~cm}$ (within the amended sediment strata). While the functional groups of the DOM in this stratum exhibited stronger binding capacities, absolute concentrations of DOM were lower. In addition to decreased capabilities of DOM:TM mobilization, the constructed wetland, may exhibit increased redox buffering capacity against tidally induced oxygen delivery through a larger FeS buffering pool (ElBishlawi et al., 2013).

The dissolved fraction of $\mathrm{Cd}, \mathrm{Cr}$, and $\mathrm{Cu}$ did not exhibit significant trends with depth, while that of $\mathrm{Fe}$ and $\mathrm{Pb}$ increased with depth. The solubility of metals increases when complexed with DOM ligands. Lower $\log K_{c}$ values indicated increased favorability for precipitation. Another indicator used to describe the tendency towards the solid phase/precipitation was the ratio of solid: dissolved trace metal concentrations. The $\log K_{c}$ of the metal: DOM complexes measured in the lab were ranked as: $\mathrm{Cd}<\mathrm{Pb}<\mathrm{Cr}<\mathrm{Cu}<\mathrm{Fe}$ (Table 1) and the solid:dissolved ratios quantified from field samples ordered as: $\mathrm{Cd}<\mathrm{Fe}<\mathrm{Cr}<\mathrm{Cu}<\mathrm{Pb}$ (Fig. S4) exhibited good agreement except for $\mathrm{Pb}$ and $\mathrm{Fe}$. In addition to DOM
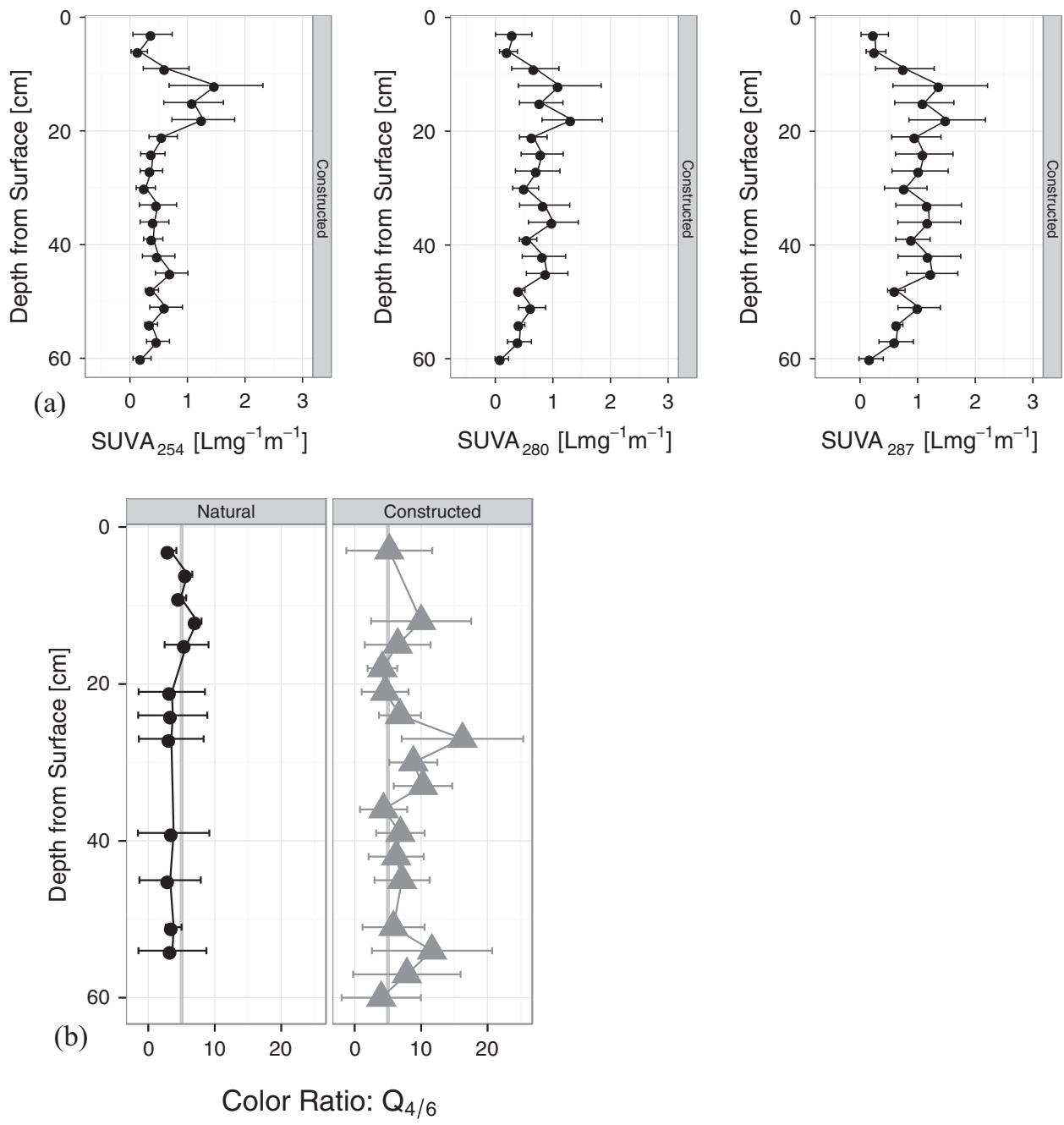

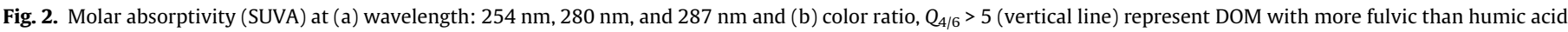
character. Values are presented with standard error. 
$\log (\mathrm{Kc})$ DOM-Cr (III)

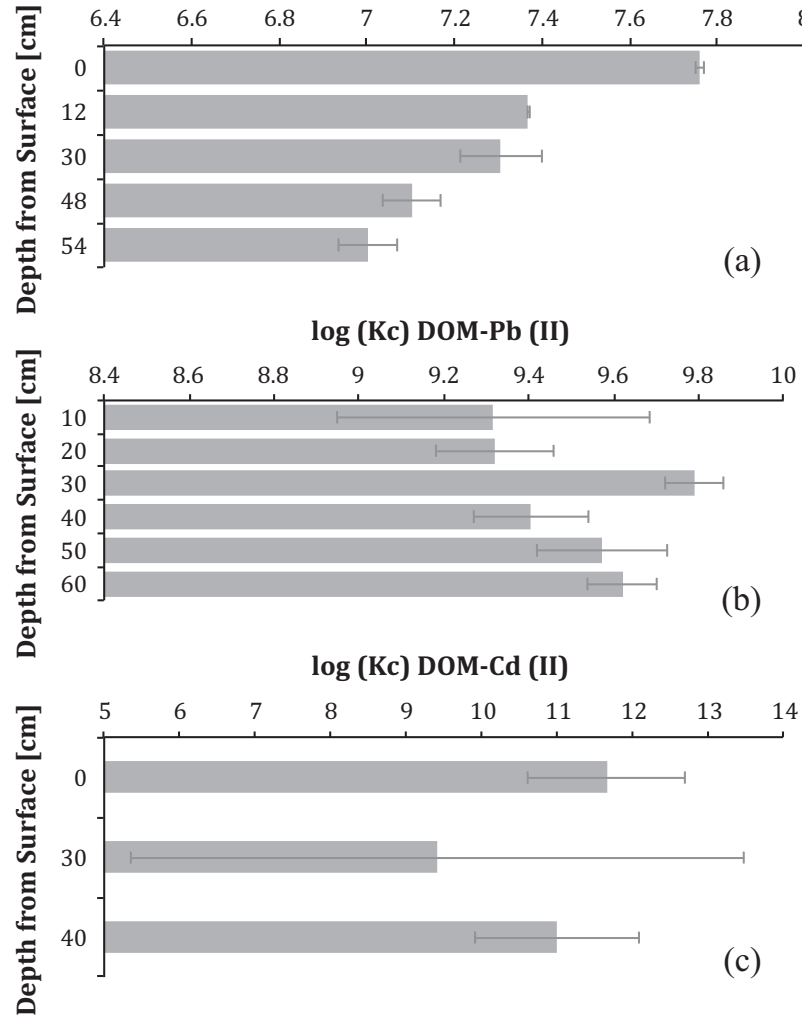

Fig. 3. Conditional stability constants $\left(\log K_{c}\right)$ along the depth profile in the constructed marsh. (a) DOM-Cr(III) samples were measured in July 2009 and plotted with associated error from 6 samples each. (b) DOM-Pb(II) samples were taken in April 2009 with associated error from at least 12 samples. (c) DOM-Cd(II) samples were taken October 2008 with associated error from at least 12 samples.

binding, other factors such as competition with iron, precipitation with sulfide, and tidally induced re-oxidation may play an important, if not controlling, in its distribution.

\subsection{Thermodynamic modeling}

To assess how DOM complexation may be affected by changes in the marsh pore-water environment, including the variability in
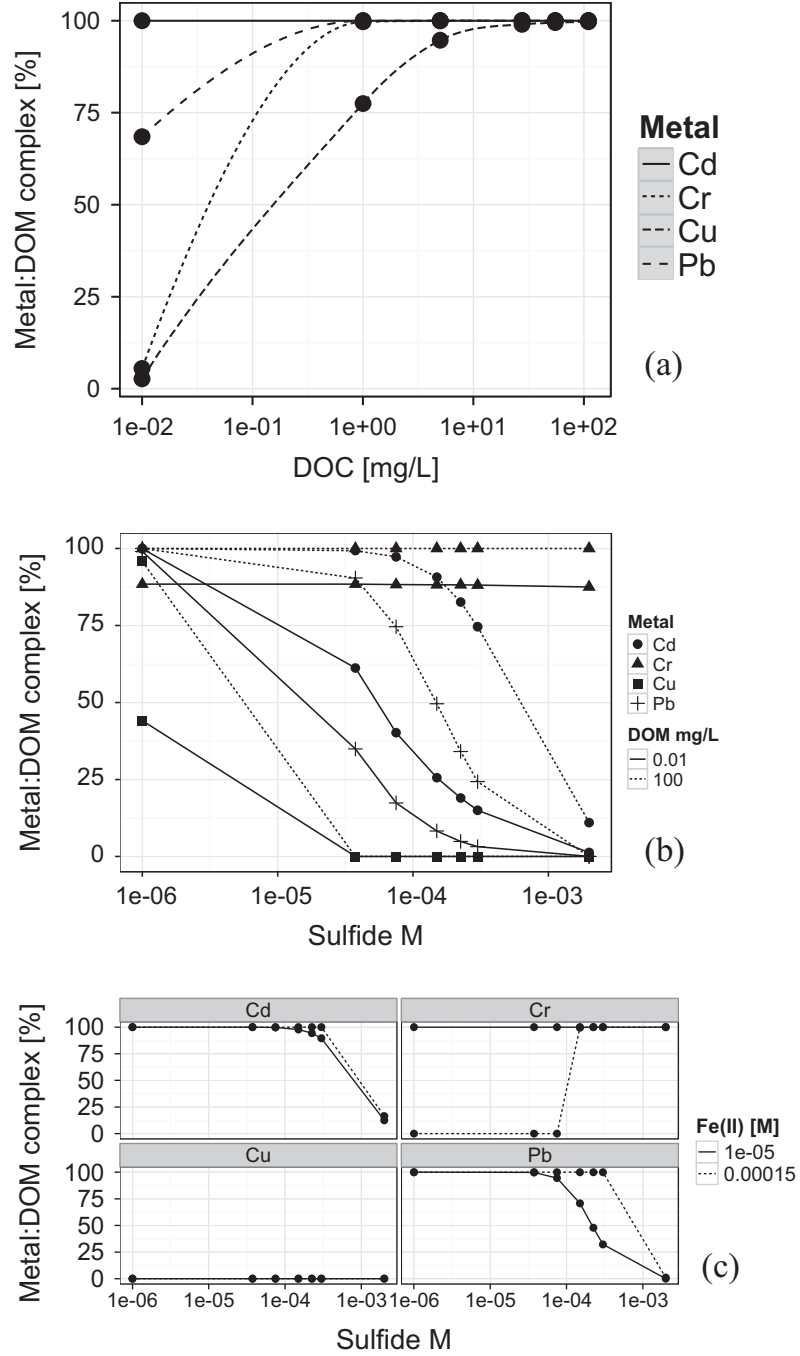

Fig. 4. Predicted metal distribution from equilibrium modeling results exhibiting change in percentage of dissolved metal complexed with DOM by varying (a) DOM concentrations $\left(0.001-100 \mathrm{mg} \mathrm{L}^{-1}\right)$, (b) sulfide (1e-6M to $2 \mathrm{e}-2 \mathrm{M}$ ) with DOM concentrations of $0.001 \mathrm{mg} \mathrm{L}^{-1}$ or $100 \mathrm{mg} \mathrm{L}^{-1}$, and (c) sulfide (1e-6M to $2 \mathrm{e}-3 \mathrm{M}$ ) with DOM concentration of $100 \mathrm{mg} \mathrm{L}^{-1}$ and $\mathrm{Fe}(\mathrm{II})$ concentrations of $(1 \mathrm{e}-5 \mathrm{M}$ and 1.5e-4M) for $\mathrm{Cd}(\mathrm{II}), \mathrm{Cr}(\mathrm{III}), \mathrm{Cu}(\mathrm{II})$, and $\mathrm{Pb}(\mathrm{II})$.

Table 1

Measured complexation constants for varying organic sources (wetland DOM (W), simulated wetland microcosm DOM (SW), and humic acid (HA) with accompanying error.

\begin{tabular}{|c|c|c|c|c|c|c|}
\hline Metal & Organic source & Depth $(\mathrm{cm})$ & Mean $\log K_{c}$ & $\mathrm{SE} \log K_{c}$ & $n$ & Metal sulfide $\log K$ \\
\hline \multirow[t]{4}{*}{$\mathrm{Cd}$} & W & $0-30$ & 10.54 & 1.83 & 24 & $14.36^{\mathrm{C}}$ \\
\hline & & $>30$ & 9.73 & 1.42 & 12 & \\
\hline & SW & - & 11.71 & 0.88 & 18 & \\
\hline & $\mathrm{HA}$ & - & $3.30^{\mathrm{a}}$ & - & - & \\
\hline \multirow[t]{3}{*}{$\mathrm{Cr}$} & $\mathrm{W}$ & $0-30$ & 7.81 & 0.34 & 18 & $9.78^{d}$ \\
\hline & & $>30$ & 7.05 & 0.05 & 12 & \\
\hline & $\mathrm{HA}$ & - & $15.22^{\mathrm{a}}$ & - & - & \\
\hline \multirow{3}{*}{$\mathrm{Cu}$} & W & - & $8.02^{\mathrm{b}}$ & - & - & $22.30^{c}$ \\
\hline & $\mathrm{HA}$ & - & 5.07 & 0.53 & 6 & \\
\hline & & - & $4.90^{\mathrm{a}}$ & - & - & \\
\hline $\mathrm{Fe}$ & $\mathrm{HA}$ & - & $6.10^{\mathrm{a}}$ & - & - & $18.51^{\mathrm{c}}$ \\
\hline \multirow[t]{4}{*}{$\mathrm{Pb}$} & W & $0-30$ & 9.62 & 0.13 & 24 & $13.97^{c}$ \\
\hline & & $>30$ & 9.55 & 0.16 & 24 & \\
\hline & $\mathrm{HA}$ & - & 5.96 & 0.07 & 6 & \\
\hline & & - & $5.20^{\mathrm{a}}$ & - & - & \\
\hline
\end{tabular}

Reference complexation constants are also provided.

a Susetyo et al. (1991)

b Brooks et al. (2007).

c Smith and Martell (2004).

d Al-Farawati and van den Berg (1999). 
trace metal, iron, and sulfide concentration, and salinity, the geochemical equilibrium model MINTEQA2 was utilized. Results shown in Fig. 4 represent the percentage of metal species bound to DOM. The marsh sediment pore-water exhibits a range of DOC values (0.01-200 $\left.\mathrm{mg} \mathrm{L}^{-1}\right)$, depending on season and depth (ElBishlawi et al., 2013). For DOM concentrations found in marsh pore-waters, dissolved metals will generally be present as a DOM complex, as opposed to existing as a free ion (Fig. 4a). As expected, increasing sulfide concentrations result in less metal availability to form DOM complexes (Fig. 4b). Using the measured $\log K_{c}$ and DOM concentrations representative of field conditions, DOM competes with sulfide for dissolved $\mathrm{Cd}, \mathrm{Cr}$, and $\mathrm{Pb}$, but not $\mathrm{Cu}$ (Fig. 4b).

The addition of iron into the model complicates the TM:DOM complexation trends because iron competes with TM for both DOM and sulfide (Fig. 4c). Depending on the relative $\log K_{c}$, iron, and sulfide concentrations, changes in TM:DOM complexation were observed with increased complexation ( $\mathrm{Cd}$ and $\mathrm{Pb}$ ), decreased complexation $(\mathrm{Cr})$, and no change in complexation $(\mathrm{Cu})$.

One major difference between the constructed marsh and natural marsh is the concentration of dissolved $\mathrm{Fe}(\mathrm{II})$. The restored marsh had abundant concentrations of dissolved iron $(150 \mu \mathrm{M})$, while concentrations of $\mathrm{Fe}(\mathrm{II})$ in the natural marsh were minimal (3 $\mu \mathrm{M})$ (ElBishlawi et al., 2013). With the tidal mixing, an abundant source of sulfate is provided to the sediments that is then reduced to sulfide. In the iron-rich amended sediments of the constructed marsh, $\mathrm{Fe}(\mathrm{II})$ is titrate out of solution with sulfide. This decrease in iron results in a decreased trace metal solubility for $\mathrm{Cd}$ and $\mathrm{Pb}$ and increased solubility for $\mathrm{Cr}$.

\section{Conclusion}

The amended sediments of the restored marsh immobilized more trace metals than original and natural marsh sediments. The differences in properties between amended surficial sediments and original deeper sediments in the constructed marsh were both lower DOC concentrations and a balance between Fe and $\mathrm{H}_{2} \mathrm{~S}$. This environment promoted a region favoring metal precipitation in the amended surficial sediments of the constructed marsh.

Noticeable differences in DOM properties and metal distributions were still observed between restored and original sediments, stratified at approximately $30 \mathrm{~cm}$, years after restoration was completed. This stratification was observed with differences in the absolute DOC concentration (change in slope of concentration profile), complexity of DOM (lower variability in functional groups and less aromatic character), and complexation capacity (higher $\log K_{c}$ values) in the restored sediments. Below $30 \mathrm{~cm}$, averages of many DOM properties converged to values observed in the natural marsh. This depth demarcates the transition from amended to original sediments. If the system were in equilibrium, observance of similar properties between original sediment of the restored marsh and natural marsh sediment would be expected (ElBishlawi et al., 2013).

Predicting the behavior of the various trace metals depended on measurement of TM:DOM complexation and bulk system parameters (DOM, iron, and sulfide concentrations). To accurately model heterogeneous DOM:metal interactions, average $\log K_{c}$ should be directly measured to represent binding strength rather than based simply upon reference humic acids. The reference humic acid exhibited higher UV absorption and underestimated binding constants for DOM:Cd and DOM:Pb and overestimated DOM:Cr as compared with the heterogeneous constructed marsh DOM. If approximations are required, the quickly established microcosms from the simulated wetland microcosm, although lower in absolute concentration, accurately represented DOM from the constructed marsh in both quality and metal complexing capacity.

\section{Acknowledgments}

This research was supported by the Meadowlands Environmental Research Institute of the New Jersey Meadowlands Commission and the Gates Millennium Scholars Fellowship.

\section{Appendix A. Supplementary material}

Supplementary data associated with this article can be found, in the online version, at http://dx.doi.org/10.1016/j.chemosphere. 2014.12.080.

\section{References}

Abate, G., Masini, J., 2002. Complexation of $\mathrm{Cd}(\mathrm{II})$ and $\mathrm{Pb}(\mathrm{II})$ with humic acids studied by anodic stripping voltammetry using differential equilibrium function and discrete site models. Org. Chem. 33, 1171-1182.

Alberts, J.J. Filip, Z., 1998. Metal binding in estuarine humic and fulvic acids: FTIR analysis of humic acid-metal complexes. Environ. Technol. 19 (9), 923-931.

Al-Farawati, R., van den Berg, C.M.G., 1999. Metal-sulfide complexation in seawater. Mar. Chem. 63, 331-352.

Andjelkovic, T., 2006. Direct potentiometric titration study of the dissociation of humic acid with selectively blocked functional groups. Eclet. Qum. 31 (3).

Baeyens, W., Goeyens, L., Monteny, F., Elskens, M., 1998. Effect of organic complexation on the behavior of dissolved $\mathrm{Cd}, \mathrm{Cu}$ and $\mathrm{Zn}$ in the Scheldt Estuary. Hydrobiologia 366, 81-90.

Baken, S., Degreyse, F., Verheyen, L., Merckx, R., Smolders, E., 2011. Metal complexation properties of freshwater dissolved organic matter are explained by its aromaticity and by anthropogenic ligands. Environ. Sci. Technol. 45 2584-2590.

Barber, L.B., Leenheer, J.A., Noyes, T.I., Stiles, E.A., 2001. Nature and transformation of dissolved organic matter in treatment wetlands. Environ. Sci. Technol. 35, 4805-4816.

Brooks, M.L., Meyer, J.S., McKnight, D.M., 2007. Photooxidation of wetland and riverine dissolved organic matter: altered copper complexation and organic composition. Hydrobiologia 57, 95-113.

Chau, Y.K., Lum-Shue-Chan, K., 1974. Determination of labile and strongly bound metals in lake water. Water Res. 8, 383-388.

Chin, Y., Aiken, G., O'Loughlin, E., 1994. Molecular weight, polydispersity, and spectroscopic properties of aquatic humic substances. Environ. Sci. Technol. 28 (11), 1853-1858.

Du Laing, G., 2008. Factors affecting metal accumulation, mobility and availability in intertidal wetlands of the Scheldt estuary (Belgium). In: Wastewater Treatment, Plant Dynamics, and Management in Constructed and Natural Wetlands. Springer Science.

Du Laing, G., Rinklebe, J., Vandecasteele, V., Meers, E., Tack, F.M.G., 2009. Trace metal behavior in estuarine and riverine floodplain soils. Sci. Tot. Environ. 407 (13), 3972-3985.

ElBishlawi, H., Shin, J.Y., Jaffe, P.R., 2013. Trace metal dynamics in the sediments of a constructed and natural urban tidal marsh: the role of iron, sulfide, and organic complexation. J. Ecol. Eng. 58 (9), 133-141.

Ephraim, J., Marinsky, J.A., 1986. A unified physicochemical description of the protonation and metal ion complexation equilibria of natural organic acids. Environ. Sci. Technol. 20, 367-376.

Fellman, J.B., D’Amore, D.V., Hood, E., Boone, R.D., 2008. Fluorescence characteristics and biodegradability of dissolved organic matter in forest and wetland soils from coastal temperate watersheds in southeast Alaska. Biogeochemistry 88, $169-184$.

Goldberg, S., 1995. Determination of labile and strongly bound metals in lake water. SSSA 42, 75.

Goldberg, S., Crescenti, L.J., Turner, D.R., Davis, J.A., Cantrell, K.J., 2007. Adsorptiondesorption processes in subsurface reactive transport modeling. Vadose Zone J 6 (3), 407.

Guo, M., Chorover, J., 2003. Transport and fractionation of dissolved organic matter in soil columns. Soil Sci. 168 (2), 108-120.

Hansell, D.A., Carlson, C.A. (Eds.), 2002. Biogeochemistry of Marine Dissolved Organic Matter. Elsevier.

Joe-Wong, C., Shoenfelt, E., Hauser, E.J., Crompton, N., Myneni, S.C.B., 2012 Estimation of reactive thiol concentrations in dissolved organic matter and bacterial cell membranes in aquatic systems. ES\&T 46 (18), 9854-9861.

Kovaleva, S., 2004. Voltammetric determination of sulfide ions. J. Anal. Chem. 59 (8), 749.

Laudon, H., Berggren, M., Agren, A., Buffam, I., Bishop, K., Grabs, T., Jansson, M. Kohler, S., 2011. Patterns and dynamics of dissolved organic carbon in boreal streams: the role of processes, connectivity, and scaling. Ecosystems 14,880 893.

Leenheer, J.A., Croue, J., 2003. Characterizing dissolved aquatic organic matter. ES\&T $1,19-26$.

Luther, G., 2001. Metal-organic complexation in the marine environment. Geochem. Trans. 9. 
MacDonald, L.H., 2010. Microbial and Plant-Driven Redox Systems in Groundwater. Princeton University.

MacDonald, L.H., Paull, J.S., Jaffe, P.R., 2013. Enhanced semi-permanent dialysis samplers for long-term environmental monitoring in saturated sediments. Environ. Monit. Assess. 185 (5), 3613-3624.

Mann, C.J., Wetzel, R.G., 1995. Dissolved organic carbon and its utilization in riverine wetland ecosystem. Biogeochemistry 31, 99-120.

Mantoura, R.F.C., Dickson, A., Riley, J.P., 1978. The complexation of metals with humic materials in natural waters. Estuar. Coast. Mari. Sci. 6, 387-408.

McKnight, D.M., Boyer, E.W., Doran, P.T., Kulbe, T., Anderson, D.T., 2001. Spectrofluorometric characterization of dissolved organic matter for indication of pre-cursor organic material and aromaticity. Limnol. Oceanogr. 46 (1), 38-48.

Mostofa, K.M.G., Liu, C., Feng, X., Yoshioka, T., Vione, D., Pan, X., Wu, F. (Eds.), 2013 Photobiogeochemistry of Organic Matter: Complexation of Dissolved Organic Matter with Trace Metal Ions in Natural Waters. Springer, New York.

Rozan, T.F., Benoit, G., Luther, G.W., 1999. Measuring metal sulfide complexes in oxic river waters with square wave voltammetry. Environ. Sci. Technol. 33 (17), 3021-3026.

Ruzic, I., 1996. Trace metal complexation at heterogeneous binding sites in aquatic systems. Mar. Chem. 53 (1-2), 1-15.

Smith, R.M., Martell, A.E., 2004. Critically Selected Stability Constants of Meta Complexes Database version 80 Standard Reference Database, vol. 46.

Sundelin, B., Erikkson, A., 2001. Mobility and bioavailability of trace metals in sulfidic coastal sediments. Environ. Toxicol. Chem. 20 (4), 748.
Susetyo, W., Carreira, L.A., Azarraga, L.V., Grim, D.M., 1991. Fluorescence techniques for metal-humic interactions. Fresenius J. Anal. Chem. 339, 624-635.

Tan, K.H., 2003. Humic Matter in Soil and the Environment. Marcel Dekker, NY, p. 84.

Tan, K.H. Giddens, JE. 1972. Molecular weights and spectral characteristics of humic and fulvic acids. Geoderma 8 (4), 221-229.

Tipping, E., 2003. Cation Binding by Humic Substances. Cambridge University Press,

USEPA, 2006. MINTEQA2 (v4.03)

Weber, W.J., McGinley, P.M., Katz, L.E., 1991. Sorption phenomena in subsurface systems: concepts, models, and effects on contaminant fate and transport. Water Res. 25 (5), 499-528.

Weishaar, J.L., Aiken, G.R., Bergamaschi, B.A., Fram, M.S., Fujii, R., Mopper, K., 2003. Evaluation of specific ultraviolet absorbance as an indicator of the chemical composition and reactivity of dissolved organic carbon. Environ. Sci. Technol. 37, 4702-4708.

Weng, L., Temminghoff, E.J.M., Lofts, S., Tipping, E., VanRiemsdijk, W.H., 2002. Complexation with dissolved organic matter and solubility control of heavy metals in a sandy soil. Environ. Sci. Technol. 36, 4804-4810.

Wetlands Act of 1970. N.J.S.A. 13:9A-1 et seq. 1970.

Winch, S., Lean, D., 2005. Comparison of changes in metal toxicity following exposure of water with high dissolved organic carbon content to solar, UVB and UVA radiation. Photochem. Photobiol. 81 (6), 1469-1480.

Zhang, J., Wang, F., 2004. Thiols in wetland interstitial waters and their role in mercury and methylmercury speciation. Limnol. Oceanogr. 49 (6), 2276-2286. 